\title{
THE ROLE OF ORGANIZATIONAL CULTURE MEDIATOR IN THE EFFECT OF KNOWLEDGE MANAGEMENT ON EMPOWERMENT AND ORGANIZATIONAL ENTREPRENEURSHIP IN SPORT ORGANIZATIONS' EMPLOYEES
}

\author{
Mohsen Taybi', Majid Keramati Moghaddam² \\ ${ }^{1}$ University of Isfahan \\ ${ }^{2}$ Azad University, Boroujerd Branch
}

Original scientific paper

\begin{abstract}
The present study aims to investigate the role of organizational culture mediator in the effect of knowledge management on empowerment and organizational entrepreneurship in sport organizations' employees. Statistics population includes all employees of Esfahan's sport boards that was selected 234 people according to Kerjcie and Morgan table as sample; but for insuring the results of data analyzing and suitable popularization, 300 questionnaires were distributed and collected 274 acceptable questionnaire. The instruments used to collect the data include Lawson (knowledge management standard questionnaire; Spritzer organizational entrepreneurship standard questionnaire; Rezaie empowerment standard questionnaire; and Robbins organizational culture standard questionnaire. Results of the study revealed that knowledge management has positive significant effects on empowerment (0.39), organizational culture (0.78), and organizational entrepreneurship (0.18) in employees of Esfahan's sport boards. Also in the indirect way, knowledge management variable on employee's empowerment according to organizational culture mediator with 0.50 coefficient, and knowledge management variable on organizational entrepreneurship according to organizational culture mediator with 0.73 coefficient has positive significant effects.

Keywords
\end{abstract}

Knowledge Management, Organizational Culture, Organizational Entrepreneurship, Empowerment, Sport Organizations Employees.

\section{INTRODUCTION AND PROBLEM STATEMENT}

Today, knowledge is a key resource of the organization and an important factor in creating a competitive advantage of organizations and is an important center of investment for management (Zand et al., 1397). Knowledge is the information that is shaped differently by combining it with business, values and insights (Nowacki \& Bachnik, 2016). Knowledge management is related to the absorption of new knowledge into the system on the one hand and to the effective management of that knowledge on the other hand (Wingate, Smith \& Perk, 2018). Knowledge management is related to the absorption of new knowledge into the system on the one hand and to the effective management of that knowledge on the other hand (Wingate, Smith \& Perk, 2018). Knowledge management is a systematic approach to identifying, managing, and sharing all On the other hand, in order not to be left out of global competition, organizations must engage in a continuous process of change so that they can stand against organizational issues and the opportunities of the complex and changing environment around them to reduce the disadvantage. And increase capabilities (Arriola et al, 2016). Therefore, in order to survive, organizations have to constantly develop their intellectual property, including databases, documentation, policies, and experiences (Herwig et al, 2015). It is also a systematic approach to discovering, understanding and using knowledge to create value. Therefore, in recent years, various organizations have begun to join the knowledge process and new concepts such as knowledge work, associate professor, knowledge management and knowledge organizations, announce the intensification of this process (Benisi, 1396). High level of knowledge management in any organization improves the quality of work, having up-to-date information, increasing efficiency, improving effectiveness, improving decision-making, increasing the ability to respond to customer needs and the possibility of rapid change and adaptability (Breznik, 2018).

capabilities and competencies to be able to respond to changing and different environmental conditions (Zand et al., 1397); In this regard, the effectiveness of knowledge management cannot be ignored (Jalali et al., 2017). In addition, fierce international competition has highlighted the importance of innovation, flexibility, accountability and collaboration in the long-term success of the 
organization. As organizations change rapidly, they must quickly adapt to new conditions and take full advantage of all new opportunities, and to strengthen the organizational entrepreneurial culture to identify changing needs (Sepahvand and Mughuinejad, 1396). Many governments around the world believe that entrepreneurship is the foundation of economic development, so they have started to present entrepreneurship development programs (Dianti and Zare Zaidi, 2017). As the environment becomes more complex and dynamic, organizations must look for entrepreneurial employees in order to identify new opportunities for sustainable sustainable performance, in addition to creating entrepreneurial conditions in the organization (Hayton, 2005).

Past research has also shown that the sustainability and development of today's organizations depend on being in line with rapid change, development and growth, in which the needs of knowledge, entrepreneurship and empowerment are strongly felt (Schneider et al, 2017). However, it must be acknowledged that the impact of organizational variables such as empowerment and promotion requires the existence of appropriate cultural and environmental conditions (Sigler \& Pearson, 2000). The rate of failure of most initiatives in the field of planned organizational change is very significant, and almost three-quarters of the efforts made in the development of an organization in various dimensions fail and fail, which in some cases even they also become threats against the organization (Zare et al., 2017). The results of several studies show that the main reason for these failures is the lack of attention to organizational culture. In other words, not paying attention to organizational culture affects other positive changes taking place (Cameron \& Quinn, 2011). In fact, one of the necessities of positive change in the current era and one of the necessary conditions for success is the existence of an optimal organizational culture governing the organization (Choi et al., 2010).

Apart from the importance and necessity of knowledge management, empowerment and entrepreneurship for different organizations, despite separate researches and studies in these fields, the impact of organizational culture on these variables is still unknown and the main shortcomings of previous researches are nonresponse. The question is, if we pay attention to these variables at the same time, what is the relationship and the extent of the impact of each of them and the important role of organizational culture on these variables.
Therefore, considering the possible impact of knowledge management on empowerment and entrepreneurship and the facilitating role of organizational culture in this, as well as the limited studies conducted in this field; The aim of this study was to investigate the effect of knowledge management on organizational empowerment and entrepreneurship of employees of sports organizations according to the mediating role of organizational culture.

\section{Theoretical Foundations Knowledge management}

One of the characteristics of the present age is the rapid change and transformation in various dimensions of societies that these changes have been reflected in all fields from the Renaissance to the present century. Given the advances in microelectronics, these changes have taken on a revolutionary aspect, and in the meantime, information technology is the engine of current changes. Although managers do things by others, but rely on a special tool called knowledge to manage the affairs of organizations (Pashanjati and Mani Yekta, 1396). The decision maker in the organization is an information processor, and today a manager is well aware that the ability to acquire, store, process and display the correct information is very important and vital in making the right decision, thus revealing the importance of knowledge and information. (Mohammadi, Henry and Kashkar, 2014). In fact, knowledge management is a conscious mechanism with the aim of providing the right knowledge to the right person at the right time (Koloniari \& Fassoulis, 2017). By using these words, Drucker announces the creation of a new type of organization, which is the main source of knowledge power. According to this theory, in the future, organizations can expect development and progress that have more knowledge. (Alwani, 1390). Therefore, today, knowledge is a strategic weapon that leads to success in the field of competition, and there are successful organizations that constantly create new knowledge and use it in product development (Prieto, Revilla \& Prado, 2009), Knowledge management is a process that provides this possibility for the organization.

Van den Hoff, Schotten, \& Simonowski (2012) consider knowledge management as a process in which individuals exchange their hidden and explicit knowledge and create new knowledge. Knowledge management is an organizational capability that allows people, technology, processes, and strategies to be integrated within 
the company to create, use, and share knowledge (Chen, 2015). This process also produces, acquires, shares, transfers and uses knowledge in the organization to increase organizational productivity (Hassanpour and Yazdani, 2012). By examining and analyzing knowledge and the importance of its features in the field of performance of organizations, it can be seen that having up-to-date knowledge and information has become a necessity for the survival of organizations (Nowruzi, Roshan and Vafadar, 2017). Knowledge management has many benefits for organizations that can be divided into two levels, individual and organizational (Benisi, 1396). At the organizational level, knowledge management has four major benefits for an organization, including improving organizational performance through efficiency, productivity, quality, and innovation. At the individual level, knowledge management also allows employees to improve their skills and experiences by working with others and sharing their knowledge and learning to achieve professional growth. Therefore, organizations consider knowledge management as a competitive strategy and advantage (Seifollahi and Davari, 2010), through which they will be able to improve many important organizational variables. Knowledge management by creating, developing and promoting knowledge and focusing on nonphysical assets of the organization (employees' experiences and knowledge) provides the conditions for the emergence of entrepreneurial behaviors and creates entrepreneurial organizations that these measures have a direct impact on Organizes economic, social and cultural growth and development (Zand et al., 1397). In fact, if organizations want to benefit from the entrepreneurial approach to achieve their goals of survival, growth and development, they must provide the conditions for entrepreneurial behavior by managing knowledge (Paksresht, 2016).

\section{Empowering employees}

In Oxford's intensive culture, the word empowerment means "empowerment, empowerment, empowerment, and empowerment" (Bina, Bordbar, and Rajabipour, 2017). The term includes the power and freedom to act for self-government, and in the organizational sense means to design the structure of the organization, so that people, while controlling themselves, are ready to accept more responsibilities ( Selajgeh, Pourrashidi and Mosaei, 2013). Empowerment of human resources as a new approach to job motivation means releasing the internal workforce of employees and providing contexts and creating opportunities for the development of talents, abilities and competencies of individuals (Samadi and Samadi, 2014). Managers should always keep in mind that people are not capable or disabled from the beginning, but the performance of the organization, especially in the field of human resources can play an effective role in empowering employees (Kazlauskaite, Buciuniene \& Turauskas, 2011).

Organizations, as a subset of human life, must prepare their employees, their core and valuable assets, for their survival and growth. Accordingly, the lack of proper use of human resources potential has become one of the most challenging problems that have plagued the present organizations and their managers (Safdarian et al., 2017). Management experts and organizational psychologists, in order to face these challenges and concerns, suggest creating a culture of employee empowerment (Abdullahi and grandson of Ibrahim, 2007). Yahya Molham (2012) in his research results states that the first factor related to the empowerment of employees is their knowledge (Jalali et al., 2017). Haririzadeh, Seyed Ahmadi, and Goodarzi (2017) also state that in order to overcome uncertain, complex, and dynamic conditions, the only way for managers is to empower the organization and its employees through the acquisition of knowledge. Also, according to the knowledge-based perspective, knowledge is the vital input of an organization and the main driver of growth and survival of human resources as the most important resource of the organization (Bina, Bordbar and Rajabipour, 1396); Therefore, the organization should always be diligent in producing knowledge and sharing it among its employees (Michaelis, Wagner and Schweizer, 2015), which seems that knowledge management can be a very powerful tool in this field for managers.

\section{Entrepreneurship}

Entrepreneurship is traditionally focused on the entrepreneur (Dianti and Zare Zaidi, 2017). Innovative and creative people take advantage of the opportunities created to start a new business or successfully develop and optimize the status quo (Rauch, Wiklund \& Frese, 2009). Schumpeter has considered entrepreneurship as the engine of economic development that is embodied in the entrepreneur (Yadalahi Farsi et al., 2011). Entrepreneurship, or the process of discovering opportunities, describes how 
individuals, independently or within organizations, address unknown issues and challenges and create a new framework of tools and goals to use. Simsek et al, 2009). Of course, the entrepreneur sees only the cases and plans to use them that have the necessary value (Lawler, 2018). Previous studies show that knowledge management has a significant contribution to the effectiveness, improvement and quality of employees' activities, which is why organizations invest a lot and effort to launch and develop it (Habibi, 2009). At the same time, it seems that knowledge management can be the driving force of employee entrepreneurship in the organization. Karl Wasser considers the lack of necessary knowledge about their activities as one of the main reasons for the failure of entrepreneurs (Moghimi, 2000); Oken also confirms this in the results of his research (Zali and Razavi, 2008). Therefore, the development of knowledge and entrepreneurship in a competitive and rapid contemporary world is a good opportunity for organizations that understand and apply it well; at the same time, it is a serious threat to organizations that pay little attention to environmental developments and do not recognize it (Mohammadi, Ghasemi and Rahmani Tabar, 2017).

\section{Organizational Culture}

To survive and thrive, and even to maintain the status quo, organizations must continue the flow of innovation and innovation to prevent stagnation and destruction, to achieve this requires a proper culture (Dong et al, 2011). Without having an effective organizational culture, one cannot expect creative activities (Sadeghi, Movahedi Sobhani and Rajabzadeh Qatari, 1397). "Understanding culture is a fundamental step in understanding the organization and the behaviors and performance of employees," says Robert Quinn. Because with the lever of culture, it is easy to facilitate changes and establish new orientations in the organization. Therefore, organizational culture is simply a key factor in the success of the organization and the realization of its long-term goals (Nowruzzadeh and Soleimani, 1396). Shin defines organizational culture as values and beliefs that are the basis of norms for the behavior expected by employees (Farhi et al., 2017). With a functionalist view of culture, it can be used as a tool to control behaviors, promote desirable behaviors and achieve better performance in the organization (Abbasi et al., 2017).

In the study of organizational behavior, organizational culture is known as a predictor of many organizational variables (Pour Zarandi, Fahima and Amir Karimi, 1396), so that its proper use can organizational performance (Jacobs, 2013); Job Satisfaction (Tong, Tak, \& Wong, 2015); Organizational Entrepreneurship (Naqdi et al., 2017); Employee commitment (Messner, 2013); Improve motivation for innovation (Büschgens, Bausch \& Balkin, 2013), capability (Pour Zarandi, Fahima and Amir Karimi, 1396; payment, payment and Giourian, 1396) and happiness (Nowruzzadeh and Soleimani, 1396).

\section{Background research}

Different internal and external researches have been done in the field of research variables, which are shown in Table (1), a summary of these researches.

In the research analytical model, knowledge management is introduced as an independent variable, empowerment and entrepreneurship are introduced as dependent variables, and organizational culture is introduced as a mediating variable. The conceptual and theoretical pattern of the relationship between the variables is shown in Figure (1).

\section{METHODOLOGY}

The present study is applied in terms of purpose; In terms of how to collect information, survey; And in terms of type, it is a causal description that is specifically based on structural equation modeling. 
Table 1. Summary of the history of domestic and foreign research

\begin{tabular}{|c|c|c|}
\hline Research description & researchers & Row \\
\hline $\begin{array}{c}\text { Knowledge management attracts the knowledge and capability of the } \\
\text { organization and employees. }\end{array}$ & $\begin{array}{l}\text { Wingate, Smith \& Perk } \\
\text { (2018) }\end{array}$ & \multirow{8}{*}{ 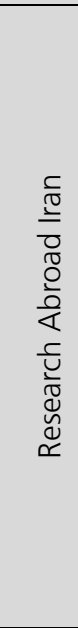 } \\
\hline $\begin{array}{l}\text { Knowledge management improves the quality of work, having up-to-date } \\
\text { information, increasing efficiency, improving effectiveness, improving decision- } \\
\text { making and the possibility of rapid change and adaptability. }\end{array}$ & Breznik (2018) & \\
\hline $\begin{array}{c}\text { Sustainability, change and development of today's organizations require } \\
\text { knowledge, entrepreneurship and empowerment. }\end{array}$ & $\begin{array}{l}\text { Schneider, Wickert \& } \\
\text { Marti (2017) }\end{array}$ & \\
\hline $\begin{array}{c}\text { The results showed that knowledge management has a significant effect on } \\
\text { employee innovation and creativity. }\end{array}$ & $\begin{array}{l}\text { Nowacki \& Bachnik } \\
\text { (2016) }\end{array}$ & \\
\hline Organizational culture will promote creativity and innovation. & $\begin{array}{l}\text { Büschgens, Bausch, \& } \\
\text { Balkin (2013) }\end{array}$ & \\
\hline $\begin{array}{l}\text { Organizational culture facilitates the ability to create knowledge in the } \\
\text { organization. }\end{array}$ & $\begin{array}{l}\text { Dong, Zhongfeng \& } \\
\text { Dongtao (2011). }\end{array}$ & \\
\hline Organizational culture will facilitate positive organizational change. & $\begin{array}{l}\text { Cameron \& Quinn } \\
\quad(2011)\end{array}$ & \\
\hline $\begin{array}{l}\text { Culture can increase the effectiveness of knowledge management by forming } \\
\text { norms and specific activities. }\end{array}$ & Tseng (2011) & \\
\hline $\begin{array}{c}\text { There is a positive and significant correlation between knowledge management } \\
\text { strategies, entrepreneurial skills and employee empowerment and their } \\
\text { dimensions with organizational effectiveness. }\end{array}$ & $\begin{array}{l}\text { Zand, Ahqr and } \\
\text { (2018) Ahmadi }\end{array}$ & \multirow{6}{*}{ 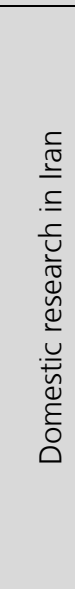 } \\
\hline $\begin{array}{l}\text { Organizational culture increases job motivation, creativity and initiative, which } \\
\text { ultimately leads to their empowerment. }\end{array}$ & $\begin{array}{l}\text { Ahmadi and Goodarzi } \\
\qquad(2017)\end{array}$ & \\
\hline $\begin{array}{l}\text { There is a positive and significant relationship between knowledge management } \\
\text { and its processes with organizational entrepreneurship. }\end{array}$ & $\begin{array}{l}\text { Mohammadi, Ghasemi } \\
\text { and Rahmani-Tabar } \\
\text { (2017) }\end{array}$ & \\
\hline $\begin{array}{l}\text { There is a positive and meaningful relationship between the components of } \\
\text { knowledge management and the dimensions of empowerment including } \\
\text { significance, sense of competence, sense of competence, self-organization, } \\
\text { acceptance of personal result and sense of participation. }\end{array}$ & $\begin{array}{l}\text { Qalavandi and Ashrafi } \\
\qquad(2017)\end{array}$ & \\
\hline $\begin{array}{c}\text { Improving or not improving organizational culture leads to increasing or } \\
\text { decreasing employee empowerment. }\end{array}$ & $\begin{array}{l}\text { Pourzarandi, Fahima } \\
\text { (2017) and Amirkabiri }\end{array}$ & \\
\hline $\begin{array}{l}\text { Findings indicate that all dimensions, components and variables of innovation } \\
\text { development are explained based on knowledge management variables. }\end{array}$ & $\begin{array}{l}\text { Poor Mozirji, Ismaili, } \\
\text { ،(2017) Hosseinzadeh }\end{array}$ & \\
\hline
\end{tabular}

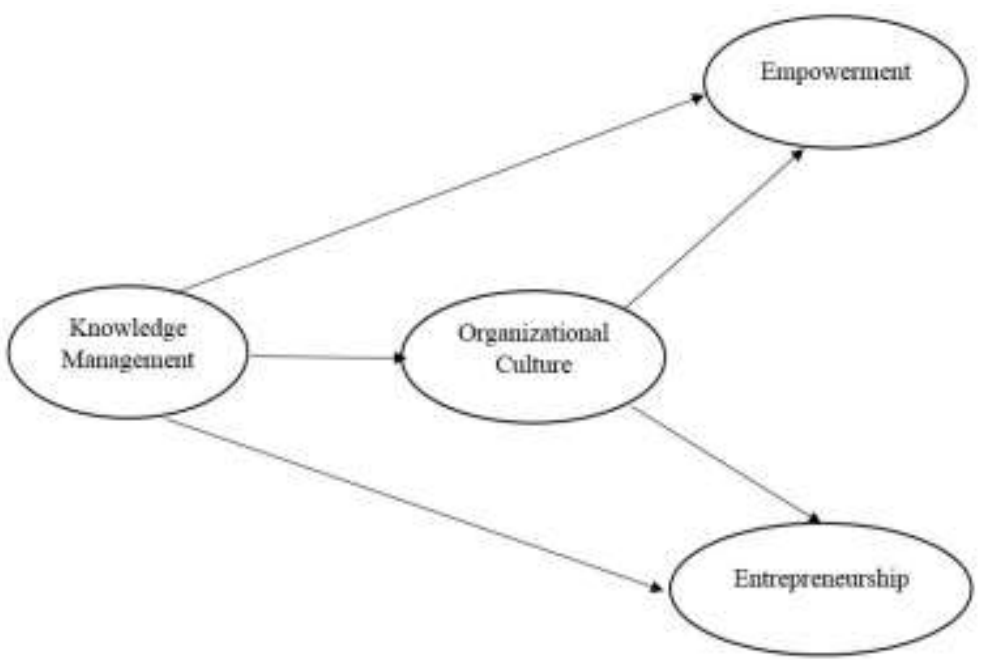

Figure (1): Conceptual model of research 
The statistical population includes all the employees of 49 sports boards of Isfahan province, which according to the inquiry from the General Department of Sports and Youth of Isfahan province, this number is 600 people. According to Krejcie and Morgan table, the number of samples for the statistical population of the present study will be at least 234 people; however, in order to ensure the results of data analysis and its generalization to the community, 300 questionnaires were distributed, of which 274 acceptable questionnaires were referred. Also, based on the sample size determination method in structural modeling studies, 10 times the number of hidden variables can provide a good estimate of the population (Davari and Rezazadeh, 2016) (230 people) that this number was less than the sample size considered. And in this regard, the set amount can provide a good estimate. The sampling method was considered stratified random according to the distribution of the population among the studied staff.

The standard Lawson (2003) questionnaire was used to measure the knowledge management variable. This questionnaire included 6 components of four questions (24 questions in total) of knowledge creation, knowledge absorption, knowledge organization, knowledge storage, knowledge dissemination, and knowledge application. Takes. To collect data on employee empowerment variables from the standard Spritzer (1995) questionnaire including 20 questions and 4 components of significance (4 questions), competence (7 questions), independence and autonomy (4 questions), and effectiveness (5). Question) was used. Rezaei Questionnaire (2014) was used to measure the organizational entrepreneurship variable of employees. This questionnaire, which is taken from the questionnaires of Antosik and Hisrich (2001), and Stachers et al. (2008), has 20 questions in the form of 4 components of risk ( 5 questions), renovation (7 questions), innovation (5 questions), foreground (3 questions) is-is. Robins (2004) modified and localized questionnaire was also used to collect data on organizational culture variable. This questionnaire has 9 components of creativity and innovation (5 questions), risk assessment ( 3 questions), attention to detail (3 questions), attention to results ( 2 questions), attention to members of the organization (5 questions), impact of decision results on employees (5 questions), attention to the team (7 questions), ambition and daring (4 questions), and sustainability (3 questions), organized in a total of 37 questions.

Although all questionnaires used were standard; however, in order to ensure their face and content validity, they were reviewed and approved using the opinions of expert professors. Also, the reliability of the questionnaires was evaluated using Cronbach's alpha test and combined reliability, which in the coefficients listed in Table (2), indicates the optimal reliability of the research questionnaire.

Table (2): Assessing the reliability of research questionnaires

\begin{tabular}{|c|c|c|c|c|}
\hline Variable & $\begin{array}{c}\text { Knowledge } \\
\text { Management }\end{array}$ & Empowerment & Entrepreneurship & Organizational Culture \\
\hline $\begin{array}{c}\text { Cronbach's alpha } \\
\text { coefficients }\end{array}$ & 0.89 & 0.92 & 0.94 & 0.94 \\
\hline Combined reliability & 0.91 & 0.93 & 0.95 & 0.95 \\
\hline
\end{tabular}

Data analysis was performed using SEM structural equation modeling in PLS SMART software.

\section{RESULTS}

R2 (square R) is an indicator to determine the fit of the model, which indicates the effect of an exogenous variable on an endogenous variable; and three values of $0.19,0.33,0.67$ are considered as the criterion index for weak, medium and strong values of R2 (Davari and Rezazadeh, 2017). Table (3) shows the coefficients R2.

The R2 values observed in Table (3) in all research variables are much higher than 0.33 and in the range of 0.67 and greater; this means that the structural model of the research has a strong fit. In PLS, it is the only GOF index that is considered as a reliable index for the overall fit of the model (both parts of the measurement and structural model), which can be calculated through the following equation. The values obtained by this formula according to the studies of Wetzels et al. (2009) can be compared and segmented with three levels of 1, 0.25 and 0.36 in three levels of weak, medium and strong. 
Table (3): $\mathrm{R}$ Square index coefficients of model endogenous variables

\begin{tabular}{|c|c|c|c|}
\hline Component & R Square & Component & R Square \\
\hline Save knowledge & 0.564 & Independence and autonomy & 0.720 \\
\hline Organizing knowledge & 0.713 & Dissemination of knowledge & 0.428 \\
\hline Risk assessment & 0.714 & $\begin{array}{c}\text { The impact of decision results on } \\
\text { employees }\end{array}$ & 0.764 \\
\hline Competence & 0.754 & Empowerment & 0.751 \\
\hline Organizational Culture & 0.610 & $\begin{array}{c}\text { Pay attention to the members of the } \\
\text { organization }\end{array}$ & 9.735 \\
\hline to be meaningful & 0.647 & Pay attention to the team & 0.536 \\
\hline To be effective & 0.728 & Attention to detail & 0.675 \\
\hline Innovation & 0.651 & Pay attention to the result & 0.525 \\
\hline Renovation & 0.844 & Ambition and daring & 0.652 \\
\hline Stability & 0.478 & Absorption of knowledge & 0.609 \\
\hline Pioneering & 0.610 & Risk-taking & 0.814 \\
\hline $\begin{array}{c}\text { Organizational } \\
\text { entrepreneurship }\end{array}$ & 0.645 & creativity and innovation & 0.603 \\
\hline Application of knowledge & 0.698 & knowledge creation & 0.375 \\
\hline
\end{tabular}

$$
\begin{gathered}
\mathrm{GOF}=\sqrt{\overline{\text { communalittes }} \times \bar{R}}= \\
\sqrt{0.596 \times 0.547}=0.692
\end{gathered}
$$

Strong overall fit Given that the GOF obtained is 0.610 , the overall fit of the model can be confirmed very strongly. To measure the relationship between structures in the structural model, significant T-values are examined. If the value of these numbers exceeds 1.96, it indicates the correctness of the relationship between the structures and thus confirms the research hypotheses at a $95 \%$ confidence level. The research model is presented in Figure (2).

Table (4) shows the coefficients of effectiveness and significance of the research model in the relationship between each of the factors with each other.

Considering that all the paths of relations between the components of the research as well as the items with each of their factors are greater than 1.96 and significant, this significance indicates the correct prediction of the relations of the research model. Based on the final research model and the results of Table (4), it is observed that the components of knowledge organization (0.844), knowledge application (0.835), knowledge absorption (0.780), knowledge storage (751) are respectively / 0$)$, knowledge dissemination (0.654), and knowledge creation (0.612) have a significant role in explaining knowledge management. In explaining the organizational entrepreneurship variable, the components of modernization (0.919), risk-taking (0.902), innovation (0.807) and pioneering (0.781), respectively, have a significant role in explaining knowledge management. The components of competence (0.868), effectiveness (0.853), independence and autonomy (0.838), and significance (0.804) also have a significant role in explaining employee empowerment. Also in the field of organizational culture variables, respectively, the components of the impact of decision results on employees (0.864), attention to members of the organization (0.857), risk assessment (0.845), attention to detail (0.822), location Ambition and daring (0.807), Creativity and innovation (0.776), Attention to team (0.732), Attention to result (0.724), and Sustainability (0.691)) have a significant role in explaining culture They are organizational. 


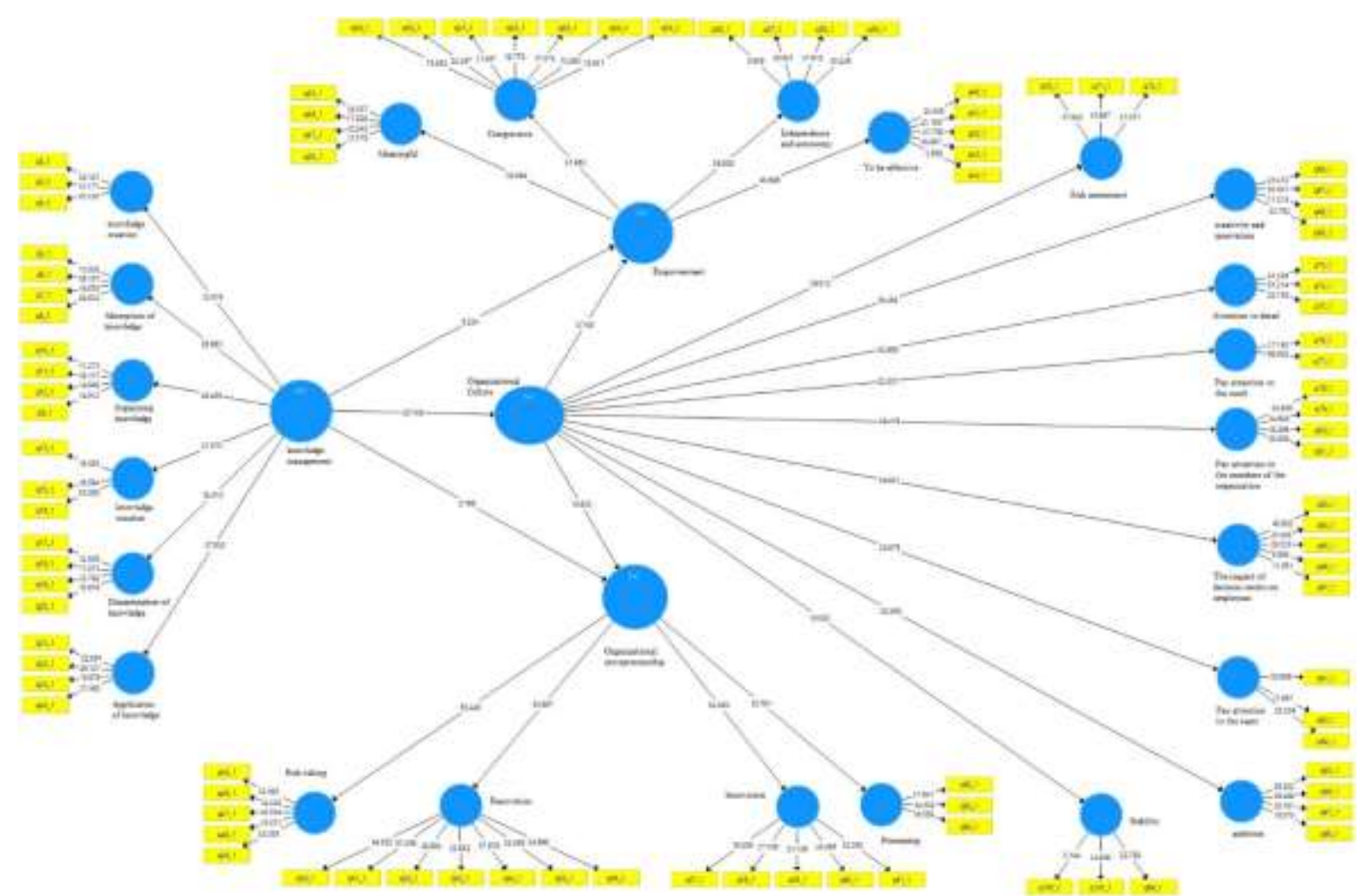

Figure (2): T-values of relationships in the research model

Based on the results of path analysis, it was found that knowledge management variable directly has a positive and significant effect on employee empowerment with an impact factor of 0.397 , organizational culture with an impact factor of 0.781 , and organizational entrepreneurship with an impact factor of 0.183 and changes explains them. The results also showed that organizational culture has a direct positive and significant effect on organizational entrepreneurship and employee empowerment and explains about $65 \%$ and $52 \%$ of the changes of these variables, respectively. Table (5) shows the study of mediating hypotheses in the research model. Sobel test is used to evaluate the effect of mediating variables; VAF statistics was also used to determine the intensity of the indirect effect of mediating variables.

The findings of Table (5) show that in the first hypothesis, ie the effect of knowledge management variable on employee empowerment and in the second hypothesis, ie the effect of knowledge management variable on organizational entrepreneurship, according to the mediation of organizational culture; $50 \%$ and $73 \%$ of the total effect of knowledge management variable on the mentioned dependent variables are explained through the mediating variable of organizational culture, respectively. 
Table (4): Significance coefficient of the relationships of each of the main factors with each other and with the sub-factors

\begin{tabular}{|c|c|c|c|}
\hline $\begin{array}{c}\text { Relationships of each of the main factors with each } \\
\text { other }\end{array}$ & $\begin{array}{l}\text { Coefficient- } \\
\text { effect }\end{array}$ & T Statistics & P Values \\
\hline Empowerment -> Independence and autonomy & 0.838 & 39.929 & 0.001 \\
\hline Empowerment -> Competence & 0.868 & 51.962 & 0.001 \\
\hline Empowerment -> Being meaningful & 0.804 & 32.694 & 0.001 \\
\hline Empowerment $->$ Effectiveness & 0.853 & 40.696 & 0.001 \\
\hline $\begin{array}{c}\text { Organizational culture -> The impact of decision } \\
\text { results }\end{array}$ & 0.864 & 59.931 & 0.001 \\
\hline Organizational Culture -> Empowerment & 0.520 & 8.749 & 0.001 \\
\hline $\begin{array}{c}\text { Organizational culture }->\text { Attention to members of } \\
\text { the organization }\end{array}$ & 0.857 & 48.479 & 0.001 \\
\hline Organizational culture -> Attention to the team & 0.732 & 23.679 & 0.001 \\
\hline Organizational culture $->$ attention to detail & 0.833 & 42.980 & 0.001 \\
\hline Organizational culture $->$ Pay attention to the result & 0.724 & 23.337 & 0.001 \\
\hline Organizational culture -> Ambition and daring & 0.807 & 32.096 & 0.001 \\
\hline Organizational Culture -> Creativity and Innovation & 0.776 & 28.459 & 0.001 \\
\hline Organizational Culture -> Risk Assessment & 0.845 & 39.912 & 0.001 \\
\hline Organizational Culture -> Sustainability & 0.691 & 16.533 & 0.001 \\
\hline $\begin{array}{c}\text { Organizational Culture }->\text { Organizational } \\
\text { Entrepreneurship }\end{array}$ & 0.652 & 10.932 & 0.001 \\
\hline $\begin{array}{c}\text { Knowledge Management -> Knowledge } \\
\text { Dissemination }\end{array}$ & 0.654 & 15.410 & 0.001 \\
\hline Knowledge Management -> Empowerment & 0.397 & 6.259 & 0.001 \\
\hline Knowledge Management -> Knowledge Absorption & 0.780 & 28.683 & 0.001 \\
\hline Knowledge Management -> Knowledge Creation & 0.612 & 12.979 & 0.001 \\
\hline Knowledge Management -> Knowledge Storage & 0.751 & 21.070 & 0.001 \\
\hline Knowledge Management -> Knowledge Organization & 0.844 & 49.406 & 0.001 \\
\hline Knowledge Management -> Organizational Culture & 0.781 & 30.748 & 0.001 \\
\hline $\begin{array}{c}\text { Knowledge Management -> Organizational } \\
\text { Entrepreneurship }\end{array}$ & 0.183 & 2.788 & 0.001 \\
\hline Knowledge Management -> Knowledge Application & 0.835 & 47.833 & 0.001 \\
\hline Organizational Entrepreneurship-> Risk-taking & 0.903 & 65.440 & 0.001 \\
\hline Organizational Entrepreneurship-> Innovation & 0.807 & 32.045 & 0.001 \\
\hline Organizational Entrepreneurship-> Modernization & 0.919 & 85.887 & 0.001 \\
\hline Organizational Entrepreneurship-> Pioneering & 0.781 & 28.781 & 0.001 \\
\hline
\end{tabular}

Table (5): Investigation of research mediating hypotheses

\begin{tabular}{|c|c|c|}
\hline Mediating hypotheses & Sobel test & VAF \\
\hline Knowledge Management -> Organizational Culture -> Empowerment & 8.131 & 0.505 \\
\hline $\begin{array}{c}\text { Knowledge Management -> Organizational Culture -> Organizational } \\
\text { Entrepreneurship }\end{array}$ & 10.258 & 0.735 \\
\hline
\end{tabular}

\section{DISCUSSION AND CONCLUSION}

Empowerment means appreciating and helping people in the organization improve their sense of self-worth; Overcome their inability or helplessness and create enthusiasm in people and provide them with internal motivation to perform job duties (Blanchard, Carlos, Randolph, 2002). Environmental change and increasing global competitiveness have focused on employee empowerment; Because organizations with capable, committed, skilled and motivated employees will be able to adapt and compete with change. According to the results obtained from the perspective of the statistical sample, knowledge management has a significant effect on employee empowerment, which can be found with the results of research by Wingitt, Smith and Perk (2018), Barznik (2018), Zand, Ahqr and Ahmadi (1397), Qalavandi and Ashrafi (1396), Jalali et al. (1396); And Yahya Mulham (2012) considered it consistent. In fact, one of the most important sources of the 21st century is knowledge and consequently knowledge management in management research (Mcfadyen, Canneila, 2004).

Although optimal access to useful information is one of the factors underlying empowerment in 
employees and in Bowen and Toller model also indicates this issue (quoted by Jalali et al., 2017); However, most organizations are ambiguous about how knowledge is formed and how knowledge management leads to empowerment (Poor Mozirji, Ismaili, and Hosseinzadeh, 2017). The results of the present study showed that organizational culture mediation can play a significant role in the impact of knowledge management on employee empowerment; In other words, organizational culture can create a good platform for the impact of knowledge management variables on employee empowerment; This finding is based on the results of research by Dong, Zhongfeng and Dongtao (2011), Cameron and Quinn (2011), Tisang (2011), Siegler and Pearson (2000), Ahmadi and Goodarzi (1396) and Pourzarandi, Fahima And Amirkabiri (1396) is consistent. Haririzadeh, Ahmadi and Goodarzi (1396) in their research results state that when organizational culture is optimally institutionalized in the organization, people perform their job duties with more motivation and enthusiasm and have higher creativity and initiative. They will show that the promotion of the mentioned cases will lead to their empowerment. The results of Pourzarandi, Fahima and Amir Kabiri (2017) also indicated that improving or not improving organizational culture leads to increasing or decreasing employee empowerment. With incompetent and unmotivated human resources, one cannot hope for the survival of an organization and ineffective use of this strategic resource will fail. Therefore, it is the duty of managers, officials, and professionals to strive to maintain, grow, and develop employees, and to establish a culture in which individuals have the motivation and ability to work and can feel effective by belonging to their organization. And guarantee its survival. On the other hand, the richer the organizational culture, the easier it will be to endure workplace problems and injustices resulting from work pressure, and the organization will have more capable employees (Payment, Payment, and Giourian, 2017).

Knowledge management is a structured process for creating, styling and understanding, transferring and applying tacit and objective knowledge and is defined as one of the organizational assets to encourage innovation and entrepreneurship (Mohammadi, Ghasemi and Rahmani-Tabar, 2017). ). One of the influential factors on organizational entrepreneurship is knowledge management, which today has become one of the main driving forces for business success. According to the results obtained from the statistical sample perspective in the present study, the effect of knowledge management on entrepreneurship was confirmed, which is consistent with the findings of Barznik (2018), Novaki and Bachnik (2016) and Mohammadi, Ghasemi and Rahmani. Descent (2017). Organizations today have become more knowledge-oriented and pay for minds instead of manual forces. Also, the need to improve knowledge is increasing; therefore, knowledge is treated systematically and exploration in the field of knowledge management is used to promote and strengthen entrepreneurship (Wong, 2005). In fact, knowledge management, by creating, developing and promoting knowledge and focusing on the non-physical assets of the organization (employees' experiences and knowledge), provides conditions for entrepreneurial behaviors and causes the emergence of entrepreneurial organizations. It has a direct effect on the economic, social and cultural growth and development of the organization (Zand et al., 2018). In fact, if organizations want to benefit from the entrepreneurial approach to achieve their goals of survival, growth and development, they must provide the conditions for entrepreneurial behavior by managing knowledge (Paksresht, 2016). In addition, the process of knowledge management and information technology with various features and capabilities can show significant development in the field of organizational entrepreneurship, which in general, some of these features are: 1) increase Speed; 2) increase accuracy; 3) Reducing the physical size of information repositories in the organization; 4) Elimination of some administrative corruption; 5) Enabling full-time work; 6) Enabling remote cooperation; And 7) Reducing the costs of the organization (Andalib, 2015). The results of the research of SIMSK et al. (2009) also showed that the effectiveness of knowledge and information technology management on entrepreneurial organizations depends on three factors: strategic use of information system, proper observation and estimation of the market and seriousness of technology users and is information systems.

Although knowledge management, as an information tool of the organization in the field of entrepreneurship, is of special importance and the creation of entrepreneurial information systems is one of the priorities to improve and enhance the level of entrepreneurship of organizations; At the same time, the results of the present study indicate that organizational culture can be the basis for greater impact of 
knowledge management on organizational entrepreneurship of employees. The results of this research in this field are consistent with the results of Buchgens, Bauch and Buckin (2013), Cameron and Quinn (2011) and Naqdi et al. (1396). Tsang (2011) also states in his research that culture can increase the effectiveness of knowledge management, because it leads to the formation of norms and specific activities. To achieve the goals of knowledge management, there must be an environment of participation, cooperation and knowledge sharing in the context of an appropriate organizational culture. Experts believe that changing the behavior of individuals and the culture that governs them is one of the executive issues of knowledge management, therefore, knowledge management projects emphasize the change of traditional trends and strengthen cultural prerequisites. Organizational culture is considered as a vital factor in creating and strengthening knowledge creation and knowledge management in the organization (Kumar, 2011).

According to the findings of the present study, the implementation of knowledge management in sports organizations, in addition to the benefits mentioned above, will lead to empowerment and entrepreneurship of employees. However, it is suggested that due to the importance of organizational culture in implementing this, in order to make positive changes and achieve the desired results, first provide the necessary conditions in the organization and implement knowledge management by creating cultural changes at all levels of the organization. . To improve this, the following is also suggested: Creating a culture and appropriate context for various aspects of implementing the knowledge management process in the organization, including improving the IT infrastructure, and staff training. Paying attention to the use of specialized staff in the use of information technology; Attention of managers and providing the necessary budget in launching and using information technology in various dimensions of sports delegations; And training and allocation of various workshops to improve staff knowledge in the use of information technology; All of which are important for the growth of the implementation of the knowledge management process; And organizational entrepreneurship should be considered by managers. According to the statistical sample, during the distribution of questionnaires, fear of the consequences of work if not successful (lack of promotion, reduction of benefits, etc.) was one of the factors of lack of creativity and entrepreneurship of employees. It is suggested to increase the support of employees in difficult and difficult situations and to provide conditions for strengthening the spirit of risk-taking (taking risks, their readiness to accept responsibility, accepting difficult work situations, having a spirit of effort, perseverance and pursuit, and Acceptance of missions in times of crisis by individuals (in employees) should be on the agenda of managers. In addition, establishing a close relationship with employees, and creating an atmosphere of trust between them, and supporting the activities and useful performance of employees and developing a reward system, is effective in creating employee service spirit and increasing their empowerment and entrepreneurship.

\section{REFERENCES}

1. Alwani, Seyed Mehdi (2011), General Management, Tehran: Ney Publications.

2. Blanchard, Kent; Carlos, John; Randolph, Allen (2002), Employee Empowerment Management, translated by Mehdi Irannejad Parizi, Tehran: Modirian Publications, third edition.

3. Benisi, Prinaz (1396), A Study of the Relationship between Knowledge Management and Emotional Intelligence with Quality of Work Life, Marine Science Education, 9, 87-97.

4. Bina, the goddess; Bordbar, Gholamreza; Rajabipour, Alireza (2017), the effect of organizational forgetfulness on human resource productivity with the mediating role of empowerment, Development Quarterly, 44, 1-28.

5. Pashanjati, Masoumeh; Mani Yekta, Roxana (2017), The relationship between marketing intelligence and knowledge management in managers of sports clubs in Tehran Municipality, Applied Research in Sports Science, Education without Borders, 2 (5), 48-59.

6. Paksrasht, Hamid (2016). Knowledge management. Tehran: Daneshkar Publications

7. Payment, eyelashes; Payment, Maliha; Giourian, Hassan (1396), The effect of organizational culture on the capabilities of employees of the Ministry of Economic Affairs and Finance, Research of Nations, 2 (21), 122 134. 
8. Payment, eyelashes; Payment, Maliha; Giourian, Hassan (1396), The effect of organizational culture on the capabilities of employees of the Ministry of Economic Affairs and Finance, Research of Nations, 2 (21), 122134.

9. Poor Zarandi, Hossein; Fahima, Maryam; Amir Karimi, Alireza (2017), The role of organizational culture in promoting psychological empowerment of employees of the banking system, economics and urban management, 19, 15-27.

10. Poor Mozirji, Morteza Valiullah; Ismaili, Abdullah Ali, Hosseinzadeh, Babak (2017), Analysis of the relationship between knowledge management dimensions and innovation in order to provide a knowledgebased innovation model, Jundishapur Education Development, 8 (3), 175-188.

11. Jalali, Ramin; Alwani, Seyed Mahdi; Hassanpour, Akbar; Mohebzadegan, Yousef (1396), Identifying and modeling the factors affecting the empowerment of naval managers, Navy Training, 8, 14-29.

12. Habibi, Ali (2009), Implementing Knowledge Management in Engineering Organizations, Tehran: Arg Publishing.

13. Haririzadeh, Masoumeh; Seyed Ahmadi Zavieh, Saeed and Goodarzi, Reza (2017), The Impact of Organizational Culture on Employee Empowerment, National Library and Information Studies Quarterly, 28 (1), 88-100

14. Hassanpour, Davood; Yazdani, Hamidreza (2012), Investigating the Relationship between Value Added of Intellectual Capital and Financial, Economic and Stock Market Performance of Companies Listed in Iran Stock Exchange, Accounting and Auditing Reviews, 19 (4), 15-32.

15. Davari, Ali; Rezazadeh, Arash (2016), Structural Equation Modeling with PLS Software, Third Edition, Tehran: Chahad Daneshgahi Publications.

16. Dianti, Rababa; Zare Zaidi, Alireza (2017), The role of human resource management in strengthening organizational entrepreneurship, Applied studies in management and development sciences, 2 (4), 1-12.

17. Zare, Amin; Ebrahimi, Christ; Sanjaqi, Mohammad Ibrahim; Ramazan, Majid (2017), Organizational Culture Management: Providing a Coherent Qualitative-Quantitative Framework as a Guide to Designing an Organizational Culture Model, Resource Management in Law Enforcement, 5 (2), 33-64.

18. Zali, Mohammad Reza; Razavi, Seyed Mostafa (2008), Research on Barriers to Entrepreneurship Development in Iran, M.Sc. Thesis, Faculty of Entrepreneurship, University of Tehran.

19. Zand, Gholamreza; Humiliation, holy; Ahmadi, Amina (1397). The Relationship between Knowledge Management Strategies, Entrepreneurial Skills and Employee Empowerment with Organizational Effectiveness and Providing an Appropriate Model, Quarterly Journal of Leadership and Educational Management, 12 (3), 141-160.

20. Sepahvand, Reza; Moghoinejad, Mahdieh (2017), the Impact of High Performance Human Resource Management on Organizational Entrepreneurship with the Mediating Role of Organizational Citizenship Behavior, Management Studies (Improvement and Transformation), 84, 53-72.

21. Poor Rashidi, Rostam; Mosaei, Mahmoud (2013), Analysis of psychological empowerment of employees and its relationship with knowledge management, Improvement and Transformation Management Studies, 72 , 99-118.

22. Seifollahi, Nasser; Davari, Mohammad Reza (2010), Knowledge Management in Organizations, Tehran: Arad Publications.

23. Sadeghi, Mohammad Taqi; Movahedi Sobhani, Farzad; Rajabzadeh Qatari, Ali (1397). Explaining the mediating role of ambivalent culture in the relationship between knowledge absorption capacity and organizational ambivalence, Organizational Culture Management, 16 (4), 871-898.

24. Safdarian, Ali; Purkiani, Massoud; Amiri, Plato; Mohammadi, Mohammad (1396); Identifying the components of individual empowerment and organizational agility in Isfahan University of Medical Sciences and examining the relationships between them, Health System Research, 13 (2), 204-210.

25. Samadi, Hussein; Samadi, Hamzeh (2014), A study of the relationship between psychological empowerment and organizational citizenship behavior of school teachers, Quarterly Journal of Leadership and Educational Management, 8 (2), 114-89.

26. Abbasi, Homayoun; Sajjadi, Nasrallah; Eidi, Hussein; Loghmani, Mohsen (2017), Explaining Organizational Culture in Sports Federations of the Islamic Republic of Iran, Sports Management and Development, 10, 2036.

27. Abdullahi, Bijan; Grandson of Ebrahim, Abdolrahim (2006), Empowering the staff of the Golden Key of Human Resource Management, Tehran: Editing Publishing.

28. Andalib, Bahareh (2015), A study of the relationship between information technology and organizational entrepreneurship with organizational agility in the General Department of Sports and Youth of Isfahan Province, Master Thesis in Sports Management, Payame Noor University, Garmsar Branch.

29. Farhi, Ali; Ebrahimi, Elham; Soltani, Mohammad Reza; Houshangi, Mehdi (2017), Assessing the current status of organizational culture according to the desired culture model: application of mixed approach, studies of organizational behavior, 6 (2), 1-25. Qalavandi, Hassan; Ashrafi Salim Kennedy, Farshid (1396). Investigating the Relationship between Knowledge Management and Empowerment in Urmia University Staff, Quarterly Journal of Educational Management Innovations, 12 (2), 123-137.

30. Mohammadi, Rozgar; Henry, Habib; Kashkar, Sara (2014), The relationship between knowledge management subsystems in the learning organization and human resource productivity in selected sports federations, Quarterly Journal of Sports Management, 20, 57-74. 
31. Mohammadi, Forough; Ghasemi, Hamid; Rahmani Tabar, Nariman (1396), Fitting the regression equation of knowledge management and organizational entrepreneurship in the staff of the Ministry of Sports and Youth, Sports Management Studies, 43, 161-184.

32. Moghimi, Seyed Mohammad (2000), Investigating the Barriers to Entrepreneurship in the Industry of the Country and Presenting Basic Solutions, Research Project, Tehran University Jihad Management Research Group, Volume 2, Final Report.

33. Babaei, Sirus; Alipour, Vahideh; Motalaei, Farhad (1396), Investigating the relationship between organizational culture based on Hofstede model and dimensions of organizational entrepreneurship, Business Management, 9 (2), 395-414

34. Nowruzzadeh, Shabnam; Soleimani, Nader (2017), Investigating the Relationship between Organizational Culture and Job Performance and Happiness of Female Staff in Tehran University of Medical Sciences and Health Services, Applied Studies in Management and Development Sciences, 2 (4), 11-20.

35. Nowruzi, elham; Roshan, Aliqoli; Vafadar, Milad (2017), Analysis of the effect of intellectual capital on organizational performance with the mediating role of knowledge management in Iran Oil Terminals Company, Training and Development of Human Resources, 4 (13), 1919-95.

36. Yadali Farsi, Jahangiri; Gholami, Nasser; Hamidi, Mehrzad; Kanani, Ali (2011), Study of Barriers to Entrepreneurship in Sports, Entrepreneurship Development, 3 (12), 105-124.

37. Arriola, K. R. J., Hermstad, A., Flemming, S. S. C., Honeycutt, S., Carvalho, M. L., \& et al. (2016). Promoting policy and environmental change in faith-based organizations outcome evaluation of a mini-grants program. Health Promotion Practice, 17(1), 146-155.

38. Breznik, K. (2018). Knowledge Management - from its Inception to the Innovation Linkage. Procedia - Social and Behavioral Sciences, 238, 141- 148.

39. Büschgens, T., Bausch, A., \& Balkin, D. (2013), Organizational culture and innovation: A meta-analytic review. Journal of Product Innovation Management, 30 (4), 763-781.

40. Cameron, K. S., \& Quinn, R. E. (2011). Diagnosing and changing organizational culture: based on the competing values framework. (3th ed), San Francisco: Jossey-Bass.

41. Chen; F. P (2015), Evaluation of knowledge management performance: An organic approach. Information Management, 52(4), 431-453.

42. Choi, Y. S., Seo, M., Scott, D., \& Martin, J. (2010). Validation of the organizational culture assessment instrument: An application of the Korean version. Journal of Sport Management, 24(2), 169-189.

43. Dong, W., Zhongfeng, S., \& Dongtao, Y. (2011). Organizational culture and knowledge creation capability. Journal of knowledge management, 15 (3), 363-373.

44. Hayton, G (2005), Promoting Corporate Entrepreneurship through Human Resource Management Practices: A Review of Empirical Research. Human Resource Management Review, 15, 21-41.

45. Herwig, C., Garcia-Aponte, O. F., Golabgir, A., \& Rathore, A. S. (2015). Knowledge management in the QbD paradigm: manufacturing of biotech therapeutics. Trends in Biotechnology, 33(7), 381-387.

46. Jacobs, R., Mannion, R., Davies, H., Harrison, S., Konteh, F., \& Walshe, K. (2013). The relationship between organizational culture and performance in acute hospitals. Social Science \& Medicine, 76, 115-125.

47. Kazlauskaite R, Buciuniene I, Turauskas L. (2011), Organizational and psychological empowerment in the HRM?. Performance linkage, Employee Relations, 34(2): 138-58.

48. Koloniari, M., \& Fassoulis, K. (2017). Knowledge management perceptions in academic libraries. The Journal of Academic Librarianship, 43(2), 135-142.

49. Kumar, R. (2011), Knowledge management and organizational culture: a theoretical integrative framework. Journal of Knowledge Management, 15 (5), 779 - 801.

50. Lawler, E. E. (2018). Understanding work motivation and organizational effectiveness: A career-long journey. Routledge: In Management Laureates.

51. Mcfadyen, M A, Canneila, J A (2004), Social capital \& knowledge creation: Diminishing return of the number and strength of exchange relationship. Academy of Management Journal, 47 (5), 735-746.

52. Messner, W. (2013), Effect of organizational culture on employee commitment in the Indian IT services sourcing industry. Journal of Indian Business Research, 5 (2), 76-100.

53. Michaelis, B., Wagner, J. D., \& Schweizer, L. (2015), Knowledge as a Key in the Relationship between HighPerformance Work Systems and Workforce Productivity. Journal of Business Research, 68(5), 1035-1044.

54. Nowacki, R., \& Bachnik, K. (2016). Innovations within knowledge management. Journal of Business Research, 69(5), 1577-1581.

55. Prieto, M.; Revilla, E.; Rodríguez-Prado, B.; (2009), Managing the knowledge paradox in product development. Journal of Knowledge Management, 13(3), 157-170.

56. Rauch, A., J. Wiklund, G., Frese, M (2009), Entrepreneurial orientation and business performance: an assessment of past research and suggestions for the future. Entrepreneurship Theory and Practice, 33(3), 761-87.

57. Schneider, A., Wickert, C., \& Marti, E. (2017). Reducing complexity by creating complexity: a systems theory perspective on how organizations respond to their environments. Journal of Management Studies, 54(2), 182-208.

58. Sigler, T., \& Pearson, C. (2000). Creating and empowering culture: examining the relationship between organizational culture and perceptions of empowerment. Journal of Quality Management, 5 (1), 27-52. 
59. Simsek, Z., Veiga, J., Lubatkin, M. \& Dino, R. N. (2009). The Role of an entrepreneurially alert information system in promoting corporate entrepreneurship. Journal of Business Research, 62 (8): 810-817.

60. Tong, C., Tak, W., \& Wong, A. (2015), The impact of knowledge sharing on the relationship between organizational culture and job satisfaction: The perception of information communication and technology (ICT) practitioners in Hong Kong. International Journal of Human Resource Studies, 5(1), 19-47.

61. Tseng, S. (2011), the effects of hierarchical culture on knowledge management processes. Management Research Review, 34(5), $595-608$.

62. Van Den Hooff, B., A. P. Schouten, Simonovski. S (2012), what one feels and what one knows: the influence of emotions on attitudes and intentions towards knowledge sharing. Journal of Knowledge Management, $16(1), 148-158$.

63. Wingate, L. A., Smith, N. L., \& Perk, E. (2018). The project vita: A dynamic knowledge management tool. Evaluation and Program Planning, 71, 22-27.

64. Wong, K. Y. (2005). Critical success factors for implementing knowledge management in small and medium enterprises. Ind Manage Data Syst, 15(3): 261-79.

Correspondence to:

Dr. Majid Keramati Moghaddam

$\mathrm{PhD}$ in Sports Management,

Azad University, Boroujerd Branch

E-mail: majid.keramatimoghadam@gmail.com 